\title{
Muhammadyah's Contribution to Education in Indonesia Case Study of The Al-Azhar Tulungagung Foundation
}

\author{
Diana Puji Lestari ${ }^{1 *}$ \\ ${ }^{1}$ Universitas Negeri Surabaya \\ *Corresponding author. Email: dianapuji.20048@mhs.unesa.ac.id
}

\begin{abstract}
As one of the largest Islamic organizations in Indonesia, Muhammadyah strives to contribute to Indonesian education. The Muhammadyah Foundation has made many contributions to education in Indonesia, from kindergarten to university level. And has been known throughout the community for its contribution to the world of education. Muhammadyah College does not only focus on the teachings of the Islamic religion but also contains general lessons, so that lecture activities are not only followed by Muslims or followers of Muhammadiyah organizations but also adherents of other mass organizations or followers of other religions. This study aims to inform that religion and education are related. Since the beginning of its formation Muhammadyah made education a path of Islamic struggle, another factor was the inefficiency of educational institutions in Indonesia at that time. One of the Mumammdyah foundations located in Tulunggangung Regency is Al-Azhar which later became the research location for conducting observations and observations. This study uses a descriptive qualitative method by analyzing events, circumstances of social phenomena. The results of Muhammadyah's research seek to guide the community into improving social life and education.
\end{abstract}

Keywords: Religion, Education, Muhammadiyah

\section{INTRODUCTION}

Education is important to build a nation. By providing insight, knowledge, and skills to the younger generation, it will produce Indonesian human resources that are no less superior to other countries' human resources. Muhammdyah as one of the Islamic organizations, from the beginning of its formation made education as a means of movement and commitment, as a form of contribution to the State. Although Muhammadiyah was founded by an Islamic group, the realm of education is not only about Islam, but also includes other general sciences. The level of education provided starts from kindergarten to college. Like the Mummadyah Al-Azhar Foundation in Tulungagung Regency which provides teaching to children. Thus, equipping children with religious values.

The vision-mission, educational concepts, goals, and curriculum provided are mutually sustainable so that Muhammadiyah can process well in society. The material developed is not only about religion but also examines more general things.

This research is not the first research that has been conducted, before that there were several studies that examined the role of Muhammadyah in providing educational efforts in Indonesia. Researchers took five studies as relevant previous research. One of them is a journal written by ST Rajiah Rudi under the title Role Of Muhammadiyah (Concept Of Education, Businesses In The Field Of Education, And Figures). What distinguishes this research from Rajiah's research is the formulation of the the informants into 2 parts,
problem taken, in this study the propright $\odot 2021$. The A uthors. Published by Atlantis Press SARL. is How the Concept of Muhammadiyah Education. Meanwhile, the formulation of the problem in the previous research was the factor behind Muhammadyah in contributing to education.

This research is a descriptive qualitative research method. The selection of informants is by using purposive sampling. The informants are students from the Muhammdyah Al-Azhar Tulungagung foundation

\section{METHODS}

In this research, the researcher used descriptive qualitative research. By analyzing events, circumstances, social phenomena that exist in society. The focus of the research is to describe the contribution of the Muhammadiyah Foundation to education in Indonesia. An in-depth analysis is needed to obtain accurate information. The qualitative research method is a research procedure that produces descriptive data, expressions or ways of the people themselves or their observed behavior. This approach leads to a holistic individual situation. Therefore, every written or spoken word of the informant observed in the individual's life is explained in its entirety [1]. This method is a reference for researchers in conducting research in the field so that they can understand and get accurate research results. The research location is the Muhammadiyah Foundation in Tulungagung Regency. The foundation provides various educational facilities from basic education to high school.

In the process of selecting informants, the researcher used purposive sampling technique. The researcher divides he informants into 2 parts, namely, 1. Key informants, key 4.0 license -http://creativecommons.org/licenses/by-nc/4.0/. 
informants and 2. supporting informants, With these two informants to strengthen the analysis of the conflicts that occurred. Collecting data in qualitative research using primary data and secondary data. Primary data is obtained directly from informants and secondary data is obtained from literature study. Data collection techniques in the form of observation, interviews, documentation, data analysis. Observation, data collection techniques with observation are used if the research is related to human behavior, work processes, natural phenomena and if the observed informants are not too large [2]. Interview, Interview is an act of communication. Interviews in research are an important or central part of qualitative research, because without interview techniques the researcher will not get important information. [3]. Documentation as evidence of events in research. Field analysis was obtained from the results of observations, interviews, and documentation.

\section{RESULT AND DISCUSSION}

\subsection{The Relationship Between Religion and Education}

Religion and education have a relationship, as well as in the formation of children's character. Religion can be used as a basis for character building so that children can develop with religious monotheism. Religion-based education is a means of conveying knowledge in religious aspects, as a means of transforming norms and moral values to form attitudes, which play a role in controlling behavior. Thus, creating a good character. Religion-based education in Muhammadyah is expected to be able to produce humans who always strive to perfect faith, piety, and noble character, noble character includes ethics, character, or morals as a manifestation of education.1 Such humans are expected to be tough in facing challenges, obstacles, and changes. that appear in the community association both in the local, national, regional and global scope.

Muhammadyah made education a path of Islamic struggle. Various efforts and activities that Muhammdyah carried out in his journey to enter the community were carried out in various fields of community life in Indonesia which were called business charities. The charity of Muhammadiyah efforts is a form of embodiment of the implementation of amar ma'ruf nahi munkar da'wah so that it can achieve its aims and objectives from its initial establishment. Charity work serves to guide the community towards improving life in the form of social and Islamic guidance. For example in the field of education. In the field of education, Muhammadiyah is growing fast, because since its inception, Muhammadiyah has made education the path of the nation's struggle. The existence of business charities in the field of education was caused by the inefficiency of educational institutions in Indonesia at that time. Charity Business in the field of education that is expected by the Muhammadiyah foundation is to be able to shape the character of youth as the next generation of the nation. With an increasingly advanced life, character and attitudes must be formed strongly so as not to be affected by bad things caused by sophistication in the world of globalization. In addition, an increasingly advanced life also requires young people to participate in developing in terms of science. $\mathrm{K}$.

H. Ahmad Dahlan Iskan is the founding figure of Muhammad, in his commitment since Muhammdyah's establishment he has strived to advance Indonesian civilization. One way is through education.

\subsection{Muhammadyah Education Concept}

As it is written in the Qur'an Q.S. Al-Mujdah: 11, that the depth of faith and the breadth of knowledge will bring humans to a higher dignity. Piety will be obtained by those who have knowledge, as stated by the educational establishment of Muhammadiyah, Abdul Mu'ti. The concept of Muhammadiyah education uses holistic. According to Ratna Megawangi, [4] the holistic concept is an educational method that builds human beings as a whole and intact by developing all human potential which includes socioemotional potential, intellectual potential, moral potential or character, creativity, and spirituality.

The concept of character education in SMP AL-Azhar Tulungagung Regency can be seen apart from the programs implemented, it can also be seen from the Vision and Mission of SMP AL-Azhar Tulungagung. In general, the vision of SMP AL-Azhar Tulungagung Regency is "The realization of students who have faith, have noble character, are devoted to parents and teachers, excel and achieve mastery learning". The vision can be implemented properly and correctly, it must be described more clearly through the existing missions. The missions pursued by SMP Al-Azhar Tulungagung are: 1 . Educate students to love and be diligent in worship. 2. Cultivate love and imitate the morals of the Prophet. 3. Educate students to have the skills to convey ideas and da'wah both orally and in writing 4. Educate students to master international languages (Arabic and English) as passive and active languages 5. Educate students to have competence in science and IT. 6. Develop students' awareness to think critically and scientifically. 7. Educate students to love and empower the surrounding natural environment.

The education curriculum at Al-Azhar Tulungagung uses a combination of the national curriculum and the Muhammadiyah curriculum. Curriculum as a component to support the course of education. The curriculum contains patterns of material and its delivery which are arranged and implemented by all elements in education. The Islamic Religious Education Curriculum (PAI) is a guideline for organizing learning activities that contains a set of plans and arrangements regarding the objectives, content, materials, and learning methods used to achieve educational goals. The flagship curriculum of Muhammadyah is the ISMUBA curriculum (Al-Islam, Kemuhammadiyahan and Arabic). In the process of formulating the curriculum, it has gone through the testing phase from experts in the field, which are found in the Muhammadiyah association which has been published by the PP Muhammadiyah Educational Education Council. After it was published, it was then distributed to Muhammadiyah schools, including the Al Azhar school in Tulungagung Regency. With the implementation of the 
ISMUBA curriculum which is relevant to the national curriculum, it must be practiced optimally and overall based on the author's observations, specifically curriculum documents such as syllabus, lesson plans, assessment books, attendance5, which are ensured to be carried out properly.

\subsection{Muhammdyah's Role in Public Education}

Muhammadyah seeks to guide the community into improving social life and education. Muhammdyahbelieves that the depth of knowledge will lead people to achieve the perfect degree of faith and piety. Muhammdyah's role in character education in the community is to form Muslim human beings who have noble character, broad views and understand worldly science problems and are willing to fight for the advancement of society at large [5]. As an organization, Muhammadiyah's struggle for movement is aimed at developing a community life system that is in accordance with the teachings of Islam. By providing education based on Islamic teachings at the Al-Azhar Tulungagung school, it is hoped that it will help shape a positive community character and live a life according to religious teachings.

\section{CONCLUSION}

Education and religion have a relationship, both of which have the same aim to build character. Religion-based education such as Islam forms children into knowledgeable and character-oriented individuals in accordance with the values of Islamic teachings. Muhammdyah as one of the Islamic organizations has a major contribution to Islamic religion-based education in Indonesia. His educational level, from kindergarten to college, has been widely known and trusted by the public. As is the case with one of the Muhammadiyah educational foundations in Tulungagung, namely the Al-Azhar school. The concept of Muhammadiyah education is to combine the national curriculum and the religious curriculum or the superior curriculum of the religion-based Muhammadiyah called ISMUBA. The concept of education is also implemented at the Al-Azhar Tulungagung school. So that it can guide students to be able to excel and guide the community in improving social and educational life.

\section{REFERENCES}

[1] Rusydi, ST Rajiah, PERAN MUHAMMADIYAH ( KONSEP PENDIDIKAN, USAHA-USAHA DI BIDANG PENDIDIKAN, DAN TOKOH), Jurnal Tarbawi| Volume 1|No 2| ISSN 2527-4082|, https://media.neliti.com/media/publications/288604peran-muhammadiyah-konsep-pendidikan-usa8bffaec8.pdf,

[2] Hasan, M. Ali \& Ali Mukti, Kapita Selekta Pendidikan Islam, Cet. 1; Jakarta; Pedoman Ilmu Jaya, 2003

[3] Zuhairini. dkk, Sejarah Pendidikan Islam, Cet. 9; Jakarta: Bumi Aksara, 2008

[4] Asy'ari, Isya. 2016. Makalah Kepemimpinan. Purwokerto: $\quad$ www.ejournal.iainpurwokerto.ac.id diakses pada Rabu, 11 September 2021

[5] Wahyuni, Dinn.. Pengantar Pendidikan. Jakarta: Universitas Terbuka, 2010

[6] Sugiyono. Memahami Penelitian Kualitatif. Bandung: Alfabeta, 2014

[7] Moleong, L.J. Metodologi Penelitian Kualitatif Edisi Revisi. Bandung: PT. Remaja Rosdakarya, 2011

[8] Wiranata, A.. Perbedaan Derajat Keasaman (pH) Saliva antara Sebelum dan Sesudah Mengunyah Buah Nanas (Ananas Comosus) pada Anak 8-10 Tahun. Repository Umy. h. 2 - 3. 2017 